Ana De Malet

Marisol García-Merino

Silvia Velasco

Carlos Ruiz de Alegría Puig

\title{
Comparison two blood culture bottles for the recovery of Enterobacteriaceae
}

Department of Microbiology, University Hospital Marqués de Valdecilla-IDIVAL, Cantabria, Spain.

Article history

Received: 21 December 2020; Revision Requested: 8 February 2021; Revision Received: 7 July 2021; Accepted: 27 July 2021;

Published: 13 September 2021

\section{ABSTRACT}

Introduction. The objective of the present study was to compare the suitability of the B BACTEC ${ }^{\mathrm{TM}}$ Lytic/10 Anaerobic/F versus B BACTEC ${ }^{\text {TM }}$ Plus Aerobic/F vials at the time of both Enterobacteriaceae recovery rate and detection time.

Material and methods. Prospective observational study from September 2018 to January 2019 in which 150 bacteremia. The samples were incubated in the automated BD BACTEC тм FX system (Becton Dickison).

Results. A total of 180 Enterobacteriaceae were isolated: 93 B BACTEC ${ }^{\text {тм }}$ Plus Aerobic/F and 87 from B BACTEC ${ }^{\text {TM }}$ Lytic/10 Anaerobic/F belonging to 106 patients The urinary focus was the most frequent origin. The average detection time in both cases was not more than 15 hours.

Conclusion. The combination of both bottles seems to be the best diagnostic strategy, thus reducing the detection time as well as increasing the recovery of Enterobacteriaceae. The combination of both vials could be implemented especially in selected situation of special urgency such as the sepsis code or critical patients.

Keywords: bacteremia, sensitivity, specificity, detection time.

Correspondence:

Ana De Malet

Department of Microbiology, University Hospital Marqués de Valdecilla-IDIVAL,

Cantabria, Spain.

E-mail:dmaletpf@hotmail.com

\section{Comparación de dos frascos de hemocultivo para la recuperación de enterobacterias}

\section{RESUMEN}

Introducción. El objetivo del presente estudio fue comparar los viales B BACTEC ${ }^{\text {TM }}$ Plus Aerobic/F y B BACTEC ${ }^{\text {TM }}$ Lytic/10 Anaerobic/F en base a la tasa de recuperación de enterobacterias y el tiempo de detección de las mismas de ambos tipos de viales.

Material y métodos. Estudio observacional prospectivo de septiembre de 2018 a enero de 2019 en el que se incluyeron 150 bacteriemias. Las muestras se incubaron en el sistema automático BD BACTEC ${ }^{\mathrm{T} M}$ FX (Becton Dickison).

Resultados. Se aislaron 180 enterobacterias: 93 B BACTEC $^{\text {TM }}$ Plus Aerobic/F y 87 de BACTEC $^{\text {TM }}$ Lytic/10 Anaerobic/F pertenecientes a 106 pacientes. El foco urinario fue el origen más frecuente. El tiempo medio de detección en ambos casos no superó las 15 horas.

Conclusión. La combinación de ambos frascos parece ser la mejor estrategia diagnóstica, reduciendo así el tiempo de detección y aumentando la recuperación de enterobacterias. La combinación de ambos viales podría implementarse especialmente en situaciones seleccionadas de especial urgencia como el código de sepsis o pacientes críticos.

Palabras clave: bacteriemia, sensibilidad, especificidad, tiempo de detección.

\section{INTRODUCTION}

Every year, approximately 750,000 patients are affected worldwide by bloodstream infections mainly by Gram-negative rods, the most lethal expression of which is sepsis [1]. In Spain affecting 100-150 in every 100,000 inhabitants/year, which accounts for more than 50,000 patients/year [2]. This has high morbidity and mortality rates (between 20-70\% [1], higher than those of death from stroke, ischemic heart disease 
or cancer. These rates tend to rise mainly due to population aging $[1,3]$. In fact, it is a great cost for health systems, estimating in the US that the average attributable expense ranges from $\$ 7,000$ in sepsis of community origin to more than $\$$ 30,000 in severe cases of hospital origin, with an average ICU stay of 3 to 8 days [4]. Given the need to act quickly in these patients, it leads to receiving empirical therapies with wide coverage [3], increasing antibiotic pressure and favouring the appearance of resistance mechanisms [1]. Furthermore, it is well known that early diagnosis improves survival and reduces hospital costs $[4,5]$.

Therefore, the early diagnosis of sepsis is a priority, with blood cultures being the gold standard for the diagnosis of bacteremia [6]. They allow the identification of any pathogen, not only those included in molecular diagnostic kits. In addition, they enable the development of sensitivity studies that offer crucial information in the management of critically ill patients [6]. However, cultivation is a slow process, and alternatives must be found to shorten the time to issue results $[7,8]$.

Bacteria in the blood are phagocytosed by macrophages $[5,9]$ and the addition of saponin as a cell lysate in the culture media can increase the concentration of microorganisms by breaking these cells, reducing their detection time [10].

Another key point is the rapid incubation of the vials and the use of automatic incubators with continuous monitoring.

The objective of the present study was to compare the suitability of the new B BACTEC ${ }^{\text {TM }}$ Lytic/10 Anaerobic/F versus B BACTEC ${ }^{\text {TM }}$ Plus Aerobic/F vials regarding to the Enterobacteriaceae recovery rate and detection times. For this, we evaluated the following parameters: i) mean and mode of the detection times, as well as the number of Enterobacteriaceae detected before 24 hours of incubation. ii) sensitivity and specificity of detection.

\section{MATERIAL AND METHODS}

Prospective observational study from September 2018 to January 2019 in which 150 bacteremia of non-pediatric patients from University Hospital Marqués de Valdecilla were studied. The amount of Enterobacteriaceae recovered from B BACTEC ${ }^{\text {TM }}$ Lytic/10 Anaerobic/F vs. B BACTEC ${ }^{\text {TM }}$ Plus Aerobic/F was compared, as well as the mean detection time, the most frequent detection time and the number of Enterobacteriaceae growing before 24 hours of incubation with both methods.

B BACTEC ${ }^{\text {TM }}$ Lytic/10 Anaerobic/F contains soy and casein digestion broth enriched with $\mathrm{CO}_{2}$ and $\mathrm{N}_{2}$ atmosphere, as well as saponin and sodium polyanetholsulfonate as novel elements that act as a lytic agent and inhibit bactericidal activities in the blood, especially the growth of anaerobic bacteria. B BACTEC ${ }^{\text {TM }}$ Plus Aerobic/F is made up of soy and casein digestion broth enriched with a $\mathrm{CO}_{2}$ atmosphere and antibiotic neutralizing resins.

The extraction of the sample was made following the norms published by Loza Fernández de Bobadilla et al [11].
In each venopuncture, a set of blood cultures was obtained consisting of one B BACTEC ${ }^{\text {TM }}$ Plus Aerobic/F and another B BACTEC $^{\text {TM }}$ Lytic/10 Anaerobic/F; the inoculated volume was a minimum of $5 \mathrm{~mL}$ per bottle and both with the same volume, verifying it visually test with different volumes or with volumes less than $5 \mathrm{~mL}$ were discarded.

The samples were incubated in the automated BD BACTEC ${ }^{\text {TM }}$ FX system (Becton Dickinson) at $37^{\circ} \mathrm{C}$ for 5 days, after which it was considered negative. The reading was done automatically every 10 minutes.

For the study, those sets that arrived at the laboratory from 8 a.m. to 3 p.m., excluding those received over the weekend and only 1 set per patient, were considered.

All the vials were treated independently. Gram staining was performed in those in which growth was detected; a subculture in standard media that was reviewed after overnight incubation. In the case of gram-negative bacilli, rapid identification was made by microculturing 3 drops of the blood culture on Mueller-Hinton-Fastidious agar and after 2 hours of incubation at $37^{\circ} \mathrm{C}$ and $5 \% \mathrm{CO}_{2}$ [10]. Identification by Maldi-Tof Vitek-MS ${ }^{\mathrm{TM}}$. Only spectra with scores of $99.9 \%$ were accepted, following manufacturer's recommendations. For lower scores, identification with overnight cultures were repeated.

Vials in which any Enterobacteriaceae were isolated were considered true bacteremia and non-true bacteremia when a microorganism belonging to the usual skin and mucosal microbiota was isolated in a single bottle or in two bottles with a normal $\mathrm{C}$ reactive protein [11]. Non-true bacteremia was only taken into account for the calculation of sensitivity and area under the curve (AUC) and considered as negative vials in recovery of Enterobacteriaceae.

Statistical analysis was performed using SPSS 20. The concordance of the results for isolates was compared with Pearson's Kappa test using B BACTEC ${ }^{\text {TM }}$ Plus Aerobic/F as a reference technique and for growth times the Wilcoxon test was used for non-parametric tests, being considered significant when $p<0.05$.

\section{RESULTS}

Three hundred bottles were studied, 150 B BACTEC ${ }^{\text {TM }}$ Plus Aerobic/F and 150 B BACTEC ${ }^{\text {TM }}$ Lytic/10 Anaerobic/F. One hundred and eighty Enterobacteriaceae were isolated: 93 from B BACTEC $^{\text {TM }}$ Plus Aerobic/F and 87 from B BACTEC ${ }^{\text {TM }}$ Lytic/10 Anaerobic/F belonging to 106 patients; the mean age was 69 years with a distribution by sex of $49 \%(n=52)$ men and $51 \%$ $(n=54)$ women. The origin of the samples was mainly from the Emergency Service (63\%), followed by Internal Medicine and Haematology, both with $8.5 \%$. The urinary focus was the most frequent origin $31 \%(n=33)$. The average detection time in both cases was 15 hours with AF and 11 hours with B BACTEC ${ }^{\text {TM }}$ Lytic/10 Anaerobic/F, showing differences statistically significant $(p=0.015)$ for the global Enterobacteriaceae and for Escherichia coli $(p=0.03)$ (Table 1). 


\begin{tabular}{|c|c|c|c|c|c|c|c|c|c|}
\hline \multirow{4}{*}{\multicolumn{2}{|c|}{$\begin{array}{c}\text { Table } 1 \\
\text { Microorganism }\end{array}$}} & ne & Its accord & isolat & terobac & ace & & & \\
\hline & & \multicolumn{4}{|c|}{ B BACTEC ${ }^{\text {TM }}$ Plus Aerobic/F } & \multicolumn{4}{|c|}{ 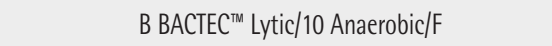 } \\
\hline & & \multirow[t]{2}{*}{$n$} & \multicolumn{2}{|c|}{ TDD } & \multirow{2}{*}{$\begin{array}{c}D C<24 H \\
n\end{array}$} & \multirow[t]{2}{*}{$n$} & \multicolumn{2}{|c|}{ TDD } & \multirow{2}{*}{$\begin{array}{c}D C<24 H \\
n\end{array}$} \\
\hline & & & $\begin{array}{c}\text { Mean } \pm \text { sd } \\
\text { (hours) }\end{array}$ & $\begin{array}{l}\text { Mode } \\
\text { (hours) }\end{array}$ & & & $\begin{array}{c}\text { Mean } \pm \text { sd } \\
\text { (hours) }\end{array}$ & $\begin{array}{l}\text { Mode } \\
\text { (hours) }\end{array}$ & \\
\hline \multicolumn{2}{|c|}{ Escherichia coli } & 59 & $11.87 \pm 9.8^{*}$ & 9.50 & 53 & 55 & $10.48 \pm 11^{*}$ & 8.50 & 52 \\
\hline \multicolumn{2}{|c|}{ Klebsiella pneumoniae } & 15 & $14.77 \pm 11.6$ & 10.50 & 12 & 13 & $10.58 \pm 7$ & 8.50 & 12 \\
\hline \multicolumn{2}{|c|}{ Enterobacter cloacae complex } & 4 & $27 \pm 33.7$ & 5.50 & 3 & 5 & $12.15 \pm 3.5$ & 11.50 & 5 \\
\hline \multicolumn{2}{|c|}{ Serratia marcenscens } & 5 & $25.20 \pm 24$ & 7 & 4 & 6 & $11.45 \pm 5.2$ & 4.50 & 6 \\
\hline \multicolumn{2}{|c|}{ Proteus mirabilis } & 2 & $11 \pm 4.2$ & 8 & 2 & 2 & $5.75 \pm 2.5$ & 4 & 2 \\
\hline \multicolumn{2}{|c|}{ Proteus penneri } & 1 & 17.75 & 17.75 & 1 & 1 & 11 & 11 & 1 \\
\hline \multicolumn{2}{|c|}{ Raoultella ornithinolytica } & 3 & $59.75 \pm 78$ & 4.50 & 1 & 1 & 4.75 & 4.75 & 1 \\
\hline \multicolumn{2}{|c|}{ Klebsiella oxytoca } & 3 & $19.92 \pm 21.3$ & 4.50 & 2 & 3 & $8.42 \pm 2.5$ & 5.50 & 3 \\
\hline \multicolumn{2}{|c|}{ Pantoea agglomerans } & 1 & 24.50 & 24.50 & 1 & 1 & 11 & 11 & 1 \\
\hline \multicolumn{2}{|l|}{ No growth } & 14 & 120 & - & - & 19 & 120 & - & - \\
\hline \multicolumn{2}{|c|}{ Total Enterobacteriaceae } & 93 & $15 \pm 16^{*}$ & 9,50 & 80 & 87 & $11 \pm 9^{*}$ & 8.50 & 84 \\
\hline
\end{tabular}

$\mathrm{n}$ : microorganisms detected; TDD: average detection time; $\mathrm{DC}<24 \mathrm{H}$ : growth detection before 24 hours of incubation; sd: standard deviation; *: statistically significant

\section{Table 2}

Results of the comparison of isolated microorganisms according to the type of the bottles.

\begin{tabular}{lcccc}
\hline & Sensitivity & AUC & Cl: $95 \%$ & K \\
\hline B BACTEC' $^{\text {TM }}$ Plus Aerobic/F & $91.8 \%$ & 0.92 & $(0.98-0.87)$ & $0.95(0.92-0.98)$ \\
\hline B BACTEC' $^{\text {tw }}$ tlyic/10 Anaerobic/F & $86.7 \%$ & 0.90 & $(0.96-0.84)$ & \\
\hline
\end{tabular}

AUC: area under the ROC curve, Cl: confidence interval, K: Kappa index.

Compared to the isolation of Enterobacteriaceae, the-B BAC$\mathrm{TEC}^{\text {TM }}$ Plus Aerobic/F were slightly better, both for having greater sensitivity and for the accuracy, although both showed very good agreement $(K \geq 0.75)$ and accuracy (AUC $\geq 0.90)$ (Table 2).

\section{DISCUSSION}

As we know, the addition of saponin or other lytic agents to the blood culture of patients with bloodstream infection facilitates the recovery of intracellular bacteria [10], a fact that can improve the isolation of Enterobacteriaceae. In our study, it was observed that the average of detection time in both bottles was not greater than 15 hours in the total number of Enterobacteriaceae, although a shorter detection time was seen in the case of E. coli in B BACTEC ${ }^{\text {TM }}$ Lytic/10 Anaerobic/F. Both bottles show similar accuracy of results, although-B BACTEC $^{\text {TM }}$ Plus Aerobic/F seem more sensitive at the time of the recovery of Enterobacteriaceae while in B BACTEC ${ }^{\text {TM }}$ Lytic/10 Anaerobic/F the mean time of detection was lower. There- fore, as a conclusion we can affirm the combination of both methods seems to be the best diagnostic strategy, decreasing the detection time by B BACTEC ${ }^{\text {TM }}$ Lytic/10 Anaerobic/F and increasing the recovery of Enterobacteriaceae with B BACTEC ${ }^{\text {TM }}$ Plus Aerobic/F.

The combination of both vials to achieve the best sensitivity and celerity in the cultures could be implemented especially in selected situation of special urgency such as the sepsis code or critical patients. Although we might think that this strategy increases the cost of the diagnostic procedure by doubling the number of blood culture vials, the B BACTEC ${ }^{\text {TM }}$ Lytic/10 Anaerobic/F vials are specially designed for the growth of anaerobic bacteria, therefore, they would allow us to maintain the same number of vials per set of blood culture extracted without detriment to diagnostic performance or increased costs

Despite all this, we encourage manufacturers of technology to detect bacteremia by blood cultures to continue working on improving these devices to shorten the detection time and increase the sensitivity of the vials. 


\section{FUNDING}

None to declare

\section{CONFLICTS OF INTEREST}

The authors declare that they have no conflict of interest.

\section{REFERENCES}

1. Bouza B, López-Cuadrado T, Saz-Parkinson Z, Amate-Blanco JM. Epidemiology and recent trends of severe sepsis in Spain: A nationwide population-based analysis (2006-2011). BMC Infect Dis. 2014; 14:3863. Doi: 10.1186/s12879-014-0717-7

2. Guna Serrano MR, Larrosa Escartín N, Marín Arriaza M, Rodríguez Díaz JC. Diagnóstico microbiológico de la bacteriemia y la fungemia: hemocultivos y métodos moleculares. Enferm Infecc Microbiol Clin 2019;37:335-340.

3. Kumar G, Ahmad S, Taneja A, Patel J, Guddati AK, Nanchal R. Severe sepsis in hematopoietic stem cell transplant recipients. Crit Care Med 2015; 43:411-21. Doi: 10.1097/CCM.0000000000000714

4. Page DB, Donnelly JP, Wang HE. Community-, Healthcare- and Hospital-Acquired Severe Sepsis Hospitalizations in the University Health System Consortium. Crit Care Med 2015; 43: 1945-1951. Doi: 10.1097/CCM.0000000000001164

5. Levy MM, Evans LE, Rhodes A. The Surviving Sepsis Campaign Bundle: 2018 update. Intensive Care Med 2018; 44:925-928. Doi: 10.1007/s00134-018-5085-0

6. Mylotte JM, Tayara A. Blood cultures: clinical aspects and controversies. Eur J Clin Microbiol Infect Dis 2000; 19:157-63. Doi: $10.1007 /$ s100960050453

7. Klouche M, Schroder U. Rapid methods for diagnosis of bloodstream infections. Clin Chem Lab Med 2008; 46:888-908. Doi: 10.1515/CCLM.2008.157

8. Tissari P, Zumla A, Tarkka E, Mero S, Savolainen L, Vaara M, et al. Accurate and rapid identification of bacterial species from positive blood cultures with a DNA-based microarray platform: an observational study. Lancet 2010; 375:224-30. Doi: 10.1016/S01406736(09)61569-5

9. Rebekka $K$, Alexander $H$, Gabriele G, Soren G. MALDI-TOF mass spectrometry following short incubation on a solid medium as a valuable tool for rapid pathogen identification from positive blood cultures. Int J Med Microbiol 2015; 305:469-479. Doi: 10.1016/j. ijmm.2015.04.004

10. Hollick GE, Edinger R, Martin B. Clinical Comparison of the BACTEC 9000 Standard Anaerobic/F and Lytic/F Blood Culture Media Diagn Microbiol Infect Dis. 1996; 24(4):191-6. Doi: 10.1016/07328893(96)00060-0

11. Rodríguez Díaz JC, Guna Serrano R, Larrosa Escartín N, Marín Arriaza M. Diagnóstico microbiológico de la bacteriemia y la fungemia: hemocultivos y métodos moleculares. 2017. 62. Procedimientos en Microbiología Clínica. Sociedad Española de Enfermedades Infecciosas y Microbiología Clínica (SEIMC). Madrid. ISBN: 978-84-697-8208-8. 